\title{
Chapter 6 \\ Creation of a TILLING Population in Barley After Chemical Mutagenesis with Sodium Azide and MNU
}

\author{
Iwona Szarejko, Miriam Szurman-Zubrzycka, Malgorzata Nawrot, \\ Marek Marzec, Damian Gruszka, Marzena Kurowska, \\ Beata Chmielewska, Justyna Zbieszczyk, Janusz Jelonek, \\ and Miroslaw Maluszynski
}

\begin{abstract}
Since the development of the Targeting Induced Local Lesions in Genome (TILLING) strategy, it has been applied in both plants and animals in many studies. The creation of an appropriate population is the first and most crucial step of TILLING. The goal is to obtain a highly mutagenized population that allows many mutations in any gene of interest to be found. Therefore, an effective method of mutation induction should be developed. A high mutation density is associated with saving time, costs, and the labor required for the development of a TILLING platform. The proper handling of the mutated generations, the establishment of a seed bank, and the development of a DNA library are essential for creating a TILLING population. The database in which all of the data from the molecular and phenotypic analyses are collected is a very useful tool for maintaining such population. Once developed, a TILLING population can serve as a renewable resource of mutations for research that uses both forward and reverse genetic approaches. In this chapter, we describe the methods for the development and maintenance of a TILLING population in barley.
\end{abstract}

Keywords Chemical mutagenesis • Alkylating agents • MNU • Sodium azide • TILLING • Barley • Phenotyping • Database

I. Szarejko $(\bowtie) \cdot$ M. Szurman-Zubrzycka $\bullet$ M. Nawrot $・$ M. Marzec $・$ D. Gruszka $・$ M. Kurowska • B. Chmielewska • J. Zbieszczyk • J. Jelonek • M. Maluszynski Department of Genetics, Faculty of Biology and Environmental Protection, University of Silesia, Jagiellonska 28, 40-032 Katowice, Poland e-mail: iwona.szarejko@us.edu.pl 


\subsection{Introduction}

Targeting Induced Local Lesions in Genomes (TILLING) is a strategy of reverse genetics that takes advantage of classical mutagenesis and high-throughput methods of mutation identification. TILLING was originally developed for Arabidopsis as an alternative to insertional mutagenesis (McCallum et al. 2000). Since then, TILLING has successfully been applied in a broad spectrum of plant species, including agronomically important crops such as barley, wheat, or maize (Kurowska et al. 2011). The objective of TILLING is to find individuals that carry mutation(s) in the gene of interest and, through the phenotypic analysis of the identified mutants and their progeny, assign a function to the analyzed gene. Furthermore, TILLING may also be performed for genes that have a known function in order to produce a series of alleles that result in different modifications in a trait of interest. The newly identified alleles can be used as a valuable resource in breeding programs. There are many successful examples of using TILLING for crop improvement, for example, in Triticum aestivum and Triticum turgidum subsp. durum for obtaining a better starch quality (Slade and Knauf 2005); in Hordeum vulgare for the manipulation of spike morphology (Gottwald et al. 2009), starch content (Sparla et al. 2014), and waterlogging tolerance (Mendiondo et al. 2016); in Cucumis melo (Dahmani-Mardas et al. 2010) and Solanum lycopersicum (Okabe et al. 2011) for enhanced shelf life; and in Sorghum bicolor (Xin et al. 2008) and Avena sativa (Chawade et al. 2010) for increased digestibility.

The first step of the TILLING strategy is the creation of a sufficiently large mutagenized population, which is called the TILLING population. Before performing mutagenesis, some crucial aspects should be considered. The first one is the material for the mutagenic treatment-because of their technical ease for seed propagated crops, such as barley, the seeds are usually treated. The second is the choice of a mutagen. Although physical mutagens such as gamma rays, thermal neutrons, and X-rays have contributed greatly to the release of mutant varieties in more than 175 plant species, including many important crops (http://mvd.iaea.org/), they have very seldom been used for the creation of TILLING populations (Sato et al. 2006). In most cases, chemical mutagens — ethyl methanesulphonate (EMS), $N$-methyl- $N$-nitrosourea (MNU), or sodium azide $\left(\mathrm{NaN}_{3}, \mathrm{SA}\right)$ - have been used for TILLING treatments in plants.

Chemical mutagens cause mainly point mutations that are irreversible and are produced in relatively high densities. Alkylating agents belong to the most commonly applied chemical compounds in plant mutagenesis. They directly alter the structure and properties of the DNA bases. These mutagens cause every type of point mutations - transitions, transversions, deletions, and frameshifts and a relatively low frequency of the chromosome breakages that cause various chromosomal rearrangements (Maluszynski et al. 2003). In most cases, chemical mutagens generate an allelic series at any target locus, which may result in a reduction in the activity, specificity, or loss of the protein function. These types of changes are very valuable in assigning a gene a function. 
The optimization of a mutagen dose before the commencement of a large-scale experiment is crucial for the successful mutagenic treatment. Simple pot tests for seedling emergence and growth reduction are routinely used to select a critical dose, i.e., a dose that results in a 50-70\% growth reduction at the seedling stage (Maluszynski et al. 2003). Such a dose causes a very high degree of sterility and lethality of $\mathrm{M}_{1}$ plants, and therefore, for plant breeding projects that are aimed at improving only one or two characters in a well-adapted variety, doses of a mutagen that cause less than a $30 \%$ growth reduction should be applied (Maluszynski et al. 2009). Too high a concentration of a mutagenic agent leads to a high lethality in the $\mathrm{M}_{1}$ populations, whereas too low a concentration of the mutagen may result in a low density of mutations. A lower frequency of mutations requires a larger mutagenized population, which is associated with higher costs and labor. Therefore, in treatments that are used for the creation of TILLING populations, doses that induce the highest frequency of point mutations in $\mathrm{M}_{2}$ plants, regardless of the somatic effects in $\mathrm{M}_{1}$, are sometimes applied (Martin et al. 2009). Nevertheless, the somatic effect of the mutagen should be known before a large-scale treatment in order to estimate the size of the $\mathrm{M}_{1}$ population required for development of a TILLING population.

Alkylating agents such as EMS and MNU mainly induce GC $>$ AT transitions (Till et al. 2003; Maluszynski et al. 2003); however, inversions and translocations have also been observed at low frequencies after MNU treatment (Szarejko and Maluszynski 1980). These mutagens cause DNA damage by transferring a methyl $\left(-\mathrm{CH}_{3}\right)$ group to the oxygen and nitrogen atoms of the nucleotide bases. A wide spectrum of lesions can be obtained, with the biological effect of these lesions ranging from less harmful to those that lead to cell death. It has been proven that methylation at the $\mathrm{O}^{6}$ position of guanine has the strongest mutagenic property, as the $\mathrm{O}^{6}$-meG mispairs with $\mathrm{T}$, and after DNA replication, the transition of G/C to A/T occurs (Richardson et al. 1986; Kleibl 2002; Warren et al. 2006). The alkylation of guanine in a nontranscribed (sense) DNA strand leads to its mispairing with thymine and after replication to its replacement by adenine ( $\mathrm{G}>\mathrm{A}$ transition). The alkylation of guanine in the transcribed (antisense) strand results in the $\mathrm{C}>\mathrm{T}$ transition.

MNU is considered to be a very strong chemical mutagen, which is sometimes called a "supermutagen" (Maluszynski et al. 2009). A detailed characterization of mutation types and frequencies induced by MNU in barley genome was reported by Kurowska et al. in 2012. The majority $(63.6 \%)$ of the MNU-induced nucleotide changes were transitions, with a similar rate of $\mathrm{G}>\mathrm{A}$ and $\mathrm{C}>\mathrm{T}$ substitutions. This indicates a lack of bias in the repair of the $\mathrm{O}^{6}$-methylguanine lesions between DNA strands. However, a strong specificity of the nucleotide surrounding the $\mathrm{O}^{6}$-meG at the -1 position was observed. Purines formed $81 \%$ of the nucleotides identified at the -1 site (Kurowska et al. 2012). In studies performed on rice, $\mathrm{G}>\mathrm{A}$ and $\mathrm{C}>\mathrm{T}$ transitions were predominant and accounted for $50 \%$ and $42 \%$ of all mutations detected, respectively (Suzuki et al. 2008). Similarly, in soybean, $90 \%$ of the observed nucleotide changes formed these two types of transitions (Cooper et al. 2008). A similar share of $\mathrm{G}>\mathrm{A}$ and $\mathrm{C}>\mathrm{T}$ transitions that has been reported in barley, rice, and soybean indicates a lack of bias in the repair of the $\mathrm{O}^{6}-\mathrm{meG}$ lesions between DNA strands. 
Another chemical—-sodium azide $\left(\mathrm{NaN}_{3}, \mathrm{SA}\right)$ - is a potent mutagen in microorganisms and a very efficient mutagen in barley as well as in some other crop species; however, it is marginally mutagenic in mammalian systems and not at all mutagenic in Neurospora sp., in Drosophila melanogaster, and in Arabidopsis thaliana (Gruszka et al. 2012). The mutagenicity of sodium azide is mediated through the production of an organic metabolite of azide - the $\beta$-azidoalanine moiety $\left[\mathrm{N}_{3}-\mathrm{CH}_{2}-\mathrm{CH}\left(-\mathrm{NH}_{2}\right)-\mathrm{COOH}\right]$. The mutagenic effect of $\mathrm{NaN}_{3}$ depends on the acidic $\mathrm{pH}$ of the treatment solution (Nilan et al. 1973). The doses of $\mathrm{NaN}_{3}$ that are routinely used for the mutagenic treatment of barley seeds are usually within the range of 0.5-4 mM for 3-5 h (Nilan et al. 1973; Maluszynski et al. 2003), although a dose as high as $10 \mathrm{mM}$ for $2 \mathrm{~h}$ was applied for the creation of a TILLMore population of cv. 'Morex' (Talamè et al. 2008). Almost all of the mutations that were identified in this population were $\mathrm{G} / \mathrm{C}>\mathrm{A} / \mathrm{T}$ transitions, while in the study performed by Olsen et al. (1993), transitions made up $86 \%$, and transversions constituted $14 \%$ of the substitutions that were induced by $\mathrm{NaN}_{3}$. In this study, the frequency of $A / T>G / C$ transitions was about three times higher than $G / C>A / T$. Deletions and mutation hot spots were not found after $\mathrm{NaN}_{3}$ treatment. The high frequency of mutations that were induced by this chemical, the low frequency of chromosome aberrations, and its low toxicity for human health (Kleinhofs et al. 1978) make sodium azide a particularly efficient mutagen that is very useful for practical barley breeding purposes (Gruszka et al. 2012; Salvi et al. 2014).

Barley TILLING populations have been established for different cultivars'Optic', 'Morex', 'Barke', 'Lux', and 'Sebastian' (Caldwell et al. 2004; Talamè et al. 2008; Gottwald et al. 2009; Lababidi et al. 2009). These populations were developed after being treated with EMS (Caldwell et al. 2004; Gottwald et al. 2009) and sodium azide (Talamè et al. 2008; Lababidi et al. 2009) or a double treatment with sodium azide and MNU. The average mutation density varied between the populations (Table 6.1).

$\mathrm{M}_{1}$ plants that are grown from treated seeds have a chimeric structure, since the multicellular tissue (seed) has been treated with mutagen. Only mutations that have been induced in germline cells are inherited, i.e., transferred to the next generation. Because of the chimeric structure of $M_{1}$ plants, screening for mutations at the molecular level is carried out in the $\mathbf{M}_{2}$ generation. Usually only one $\mathbf{M}_{2}$ plant is grown from each $\mathrm{M}_{1}$ plant in order to avoid the reappearance of the same mutations. DNA is individually isolated from each $\mathrm{M}_{2}$ plant, and then DNA samples are pooled together prior to genotypic screening to increase the throughput of mutation discovery (usually five- to eightfold DNA pools are prepared). All $\mathrm{M}_{2}$ plants are basically phenotyped and harvested, and a seed bank is established for $\mathrm{M}_{3}$ seeds. It is beneficial to create a database in order to store information about the mutated generations, the phenotypes of the $\mathrm{M}_{2}$ individuals and $\mathrm{M}_{3}$ lines, the gene sequences analyzed, the types of mutations detected, the availability of $\mathrm{M}_{2}$ and $\mathrm{M}_{3}$ seeds, etc.

There are many different methods for mutation identification (e.g., see Chaps. 17, 18, 19, and 20 of this book). After the identification of an $\mathbf{M}_{2}$ plant carrying a mutation in the gene of interest, it is important to develop a homozygous line for phenotyping. If the $\mathrm{M}_{2}$ plant carries a mutation in the homozygous state, it 
Table 6.1 Mutation density in different barley TILLING populations

\begin{tabular}{|c|c|c|c|}
\hline Cultivar & Mutagen & Mutation density & References \\
\hline Optic & EMS & $1 / 1000 \mathrm{kbp}$ & Caldwell et al. (2004) \\
\hline Morex & $\mathrm{NaN}_{3}$ & $1 / 374 \mathrm{kbp}$ & Talamè et al. (2008) \\
\hline Barke & EMS & $1 / 500 \mathrm{kbp}$ & Gottwald et al. (2009) \\
\hline Lux & $\mathrm{NaN}_{3}$ & $1 / 2500 \mathrm{kbp}$ & Lababidi et al. (2009) \\
\hline Sebastian & $\mathrm{NaN}_{3}$ and $\mathrm{MNU}$ & $1 / 477 \mathrm{kbp}$ & This paper \\
\hline
\end{tabular}

is possible to perform phenotypic analysis directly in the $\mathrm{M}_{3}$ progeny and further generations. However, if the mutation is in the heterozygous state in the analyzed $\mathrm{M}_{2}$ plant, it is necessary to select plants that carry the mutation in the homozygous state in $\mathrm{M}_{3}$ generation. A large number of seeds are required for many phenotyping experiments, and therefore it is always recommended that the material be multiplied before analysis.

Phenotypic analysis of allelic mutants identified through TILLING may reveal the function of the gene of interest. However, it has to be borne in mind that after effective mutagenesis, many mutations are generated in a plant genome. For example, in barley, whose genome size is $5.1 \mathrm{Gbp}$ (IBGSC 2012), each $\mathrm{M}_{2}$ plant may carry circa 10,000 mutations, assuming that the mutation density in the TILLING population is $1 / 500 \mathrm{~kb}$. The majority of these mutations are in intergenic regions or in introns, but there is a possibility that an $\mathrm{M}_{2}$ plant carrying a mutation in the gene of interest may also carry other mutations (in different genes) that influence the phenotype. To clean the genetic background of the mutant from unwanted mutations, backcrosses with the parent variety should be carried out. However, in order to confirm that the altered phenotype is a consequence of the identified mutation, the co-segregation analysis of the mutation and a specific phenotypic trait should be performed.

The creation of a TILLING population is strictly associated with the production of a large amount of data that has to be safely stored and made available for population designers and for future users of the developed TILLING platform. Most of the available databases contain data on 5000-13,000 plants of the $\mathrm{M}_{2}$ population (reviewed by Kurowska et al. 2011). The planning and creation of a TILLING population have to be preceded by a decision about how to provide the generated data to the recipients. It should be noted that the availability of a database containing detailed information about a TILLING population on the Internet significantly increases the impact of the studies being performed (Coronel and Morris 2016). In this manual, we present a version of a database that can be shared on the Internet.

There are many different ways to establish databases for a TILLING population, and various programs can be used to design them, including freeware and commercial software. For the Internet-available databases, phpMyAdmin is a useful program that allows simple and sophisticated databases to be developed that are easily accessed via the WWW. In combination with Internet platforms created using HTML and PHP languages, there are enormous possibilities for presenting, 
storing, and searching data without increasing the costs of the development of a TILLING population (Miller 2014).

In this chapter, we describe the creation of a TILLING population for barley after combined treatment with two chemical mutagens: sodium azide and MNU. The application of a double mutagenic treatment with a period of inter-incubation germination of seeds between treatments gave a high frequency of point mutations in barley (Szarejko and Maluszynski 1999) and rice (Till et al. 2007). The TILLING population that was developed in barley after the combined treatment with sodium azide and MNU has been successfully used for the functional analysis of the genes involved in the control of DNA repair (Stolarek 2015a, b), waterlogging (Mendiondo et al. 2016), and strigolactone perception (Marzec et al. 2016).

\subsection{Materials}

\subsubsection{Mutagenesis}

1. Seeds (see Note 1)

2. Sodium azide $\left(\mathrm{SA}, \mathrm{NaN}_{3}\right)$ (e.g., Sigma-Cat. No. S2002)

3. $N$-methyl- $N$-nitrosourea (MNU) (e.g., Oakwood Chemical-Cat. No. 098373)

4. $\mathrm{KH}_{2} \mathrm{PO}_{4}$ and $\mathrm{H}_{3} \mathrm{PO}_{4}$ for the preparation of a phosphate buffer

5. Distilled water

6. Equipment:

- Laboratory fume hood

- Laboratory balance $(0.001-100 \mathrm{~g})$

- Laboratory balance (0.01-2000 g)

- Beakers (0.5 L, 1 L, 2 L)

- Measuring cylinders (different sizes)

- Trays with filter paper

\subsubsection{Handling of Mutated Population}

1. Soil and vermiculite

2. Pots (e.g., square- $13 \times 13 \times 13 \mathrm{~cm}$ pots)

3. Water-soluble 22:5:10 fertilizer (N-P-K)

4. Equipment:

- Vacuum packer (e.g., Tepro PP5.4)

- Freezers for seed storage

5. Greenhouse or a growth chamber 


\subsubsection{DNA Isolation}

1. Leaf fragments of $\mathrm{M}_{2}$ plants (2-3 fragments, $2 \mathrm{~cm}$ long)

2. Silica gel (e.g., Sigma-Cat. No. 10087)

3. Glass beads (diameter, $3 \mathrm{~mm}$ ) (e.g., Sigma - Cat. No. Z265926)

4. CTAB extraction buffer containing $2 \%$ CTAB, $100 \mathrm{mM}$ TrisHCl, $20 \mathrm{mM}$ EDTA, $1.4 \mathrm{M} \mathrm{NaCl}$, and $1 \% \beta$-mercaptoethanol (the last ingredient should be added to the appropriate volume of buffer immediately before use) (see Note 2)

5. Solution of chloroform-isoamyl alcohol (in 24:1 ratio)—should be kept in dark

6. $96 \%$ and $70 \%$ ethanol

7. TE buffer containing $10 \mathrm{mM}$ TrisHCl and $1 \mathrm{mM}$ EDTA

8. RNAse solution containing $1 \%$ RNAse A, $9 \mathrm{mM}$ sodium acetate, and $90 \mathrm{mM}$ TrisHCl

9. Equipment:

- Laboratory fume hood

- Electric mill (e.g., Retsch MM 200, Retsch MM 301) or tissue homogenizer (e.g., FastPrep ${ }^{\circledR}-24$, MP Biomedicals)

- Water bath or thermomixer

- Centrifuge for Eppendorf tubes that enable spinning at $18,000 \times g$ at $4{ }^{\circ} \mathrm{C}$

- Vacuum concentrator (e.g., SpeedVac, Savant)—optional

- Spectrophotometer (e.g., NanoDrop ND-1000)

\subsubsection{Creation of a Database}

1. A server connected to the Internet for a database that is available in the WWW (see Note 3)

2. Program for designing a database (see Note 4)

\subsection{Methods}

\subsubsection{Mutagenesis}

\subsubsection{General Remarks}

1. Mutagens are dangerous; take appropriate safety precautions (see Note 5).

2. Carefully plan out experiments in advance (see Notes 6-8). 


\subsubsection{Mutagenic treatment}

1. Before a large-scale mutagenic treatment, evaluation of a critical dose of mutagen is recommended. Use $4-5$ doses of mutagen, e.g., $1.0 \mathrm{mM}, 1.5 \mathrm{mM}$, $2.0 \mathrm{mM}, 2.5 \mathrm{mM}$, and $3.0 \mathrm{mM}$ sodium azide and $0.5 \mathrm{mM}, 1.0 \mathrm{mM}, 1.5 \mathrm{mM}$, $2.0 \mathrm{mM}$, and $2.5 \mathrm{mM} \mathrm{MNU}$; duration of treatment-3 h (see Note 8). Use simple laboratory tests for seedling emergence and growth reduction in order to establish the critical dose of a mutagen.

2. Calculate the amount of seeds needed for treatment. For laboratory tests, use 300 seeds ( 3 replications $\times 100$ seeds) plus a few seeds for eventual loss. For a large-scale treatment, use the number of seeds estimated on the basis of evaluation of somatic effects of the mutagen (see Note 9).

3. Put the seeds into a labeled glass container.

4. Presoak seeds in an excess of $\mathrm{dH}_{2} \mathrm{O}$ for $8-12 \mathrm{~h}$ (see Note 10). The amount of water used in presoaking should be at least two to three times the volume of dry seeds. The beakers with presoaked seeds should be gently shaken a few times to remove air bubbles, which can block access of mutagen to embryos.

5. Calculate the amount of solutions needed for all of the treatment combinations. For small grain seeds, such as barley, use $0.5 \mathrm{ml}$ of solution per one seed.

6. For treatment with sodium azide, prepare phosphate buffer, $\mathrm{pH}=3.0$ (see Note 11). Use $54.436 \mathrm{~g} \mathrm{KH}_{2} \mathrm{PO}_{4}$ and add $3.67 \mathrm{ml} \mathrm{H}_{3} \mathrm{PO}_{4}$ per $1 \mathrm{~L}$ buffer. The buffer will be needed for all of the treatment combinations including the control.

7. Prepare the mutagenic solutions starting from the basic solution (the highest concentration used for treatment). Dissolve sodium azide in the buffer while MNU in distilled water. Leave a part of this solution for treatment, and dilute the rest to the required concentrations according to the calculations done. You can use a formula: $\mathbf{C}_{\mathbf{1}} \times \mathbf{V}_{\mathbf{1}}=\mathbf{C}_{\mathbf{2}} \times \mathbf{V}_{\mathbf{2}}$, where $\mathrm{C}_{1}$ is the concentration of the basic solution, $\mathrm{V}_{1}$ volume of the basic solution, $\mathrm{C}_{2}$ concentration of the solution required, and $\mathrm{V}_{2}$ volume of the solution required. Use a fume hood for the preparation of mutagenic solutions (see Note 5).

8. Before treatment, pour out the $\mathrm{dH}_{2} \mathrm{O}$ from the containers with seeds and rinse the seeds twice in tap water. Be careful to completely remove the water after rinsing.

9. Perform the treatment, i.e., pour the mutagen solutions into the beakers with the presoaked and rinsed seeds. Use a fume hood for treatment. Keep the same order of combinations during the whole procedure, i.e. presoaking, rinsing, treatment, and rinsing after treatment. Perform the mutagenic treatment at room temperature.

10. After $3 \mathrm{~h}$ of treatment, pour out the mutagenic solutions and rinse the seeds thoroughly in running tap water, minimum three to four times (see Note 12). Be careful not to lose any seeds (see Note 13). 
11. For a double treatment with two mutagens, a 5-6-h period of inter-incubation germination is applied. After 3-h treatment with sodium azide (the first applied mutagen) and thorough rinsing, put the seeds into trays with a few layers of a filer paper, cover them with a wet sheet of the filter paper and keep for $6 \mathrm{~h}$ at room temperature. Then transfer seeds into the labeled beakers and pour the mutagenic solution with the second applied mutagen, i.e., MNU. Treat the seeds for $3 \mathrm{~h}$ and then rinse them in running tap water.

12. Plant $M_{1}$ seeds. If you perform a pot test for seedling emergence and growth reduction, see protocol below (Sect. 6.3.1.3). If you treat the seeds for a largescale experiment to obtain $M_{1}$ generation for TILLING, plant the seeds into pots as described in Sect. 6.3.2. If you cannot plant $\mathbf{M}_{1}$ seeds immediately after treatment, completely dry the seeds on a filter paper and store them until sowing in plastic bags at $4{ }^{\circ} \mathrm{C}$. The treated seeds can be stored in a refrigerator for a few weeks.

\subsubsection{Evaluation of a Critical Dose of Mutagens}

1. Mix the soil with the vermiculite (2:1); wet the mixture.

2. Fill the pots (13-15 cm diameter) with the mixture to $3 \mathrm{~cm}$ from the top.

3. Label the pots (genotype, mutagen concentration (dose), replication).

4. Plant 100 seeds per replication into each labeled pot.

5. Cover with a $3-\mathrm{cm}$ layer of wet sand.

6. Place the pots randomly into the growth chamber at temperature $22{ }^{\circ} \mathrm{C} / 20{ }^{\circ} \mathrm{C}$ day/night, 16/8 photoperiod, and light intensity at least $200 \mu \mathrm{mol} \mathrm{m}{ }^{-2} \mathrm{~s}^{-1}$ and grow them till the emergence of the second leaf (Fig. 6.1).

7. Seven to ten days after the mutagenic treatment, cut all of the seedlings near the surface of the sand, count their number, and measure their length (separately for each variety, dose, and replication).

8. Calculate the mean $\pm \mathrm{SD}$ of the seedling number and length separately for each mutagenic combination.

9. Calculate the seedling emergence reduction and seedling growth reduction for each combination. Use the following formulas:

Seedling emergence reduction $(\%)=1-$ Average number of seedlings in a treated combination/Average number of seedlings in the control $\times 100 \%$

Seedling growth reduction $(\%)=1$-Average length of seedlings in a treated combination/Average length of seedlings in the control $\times 100 \%$

10. Select one to two doses for a large-scale treatment (see Note 9). 

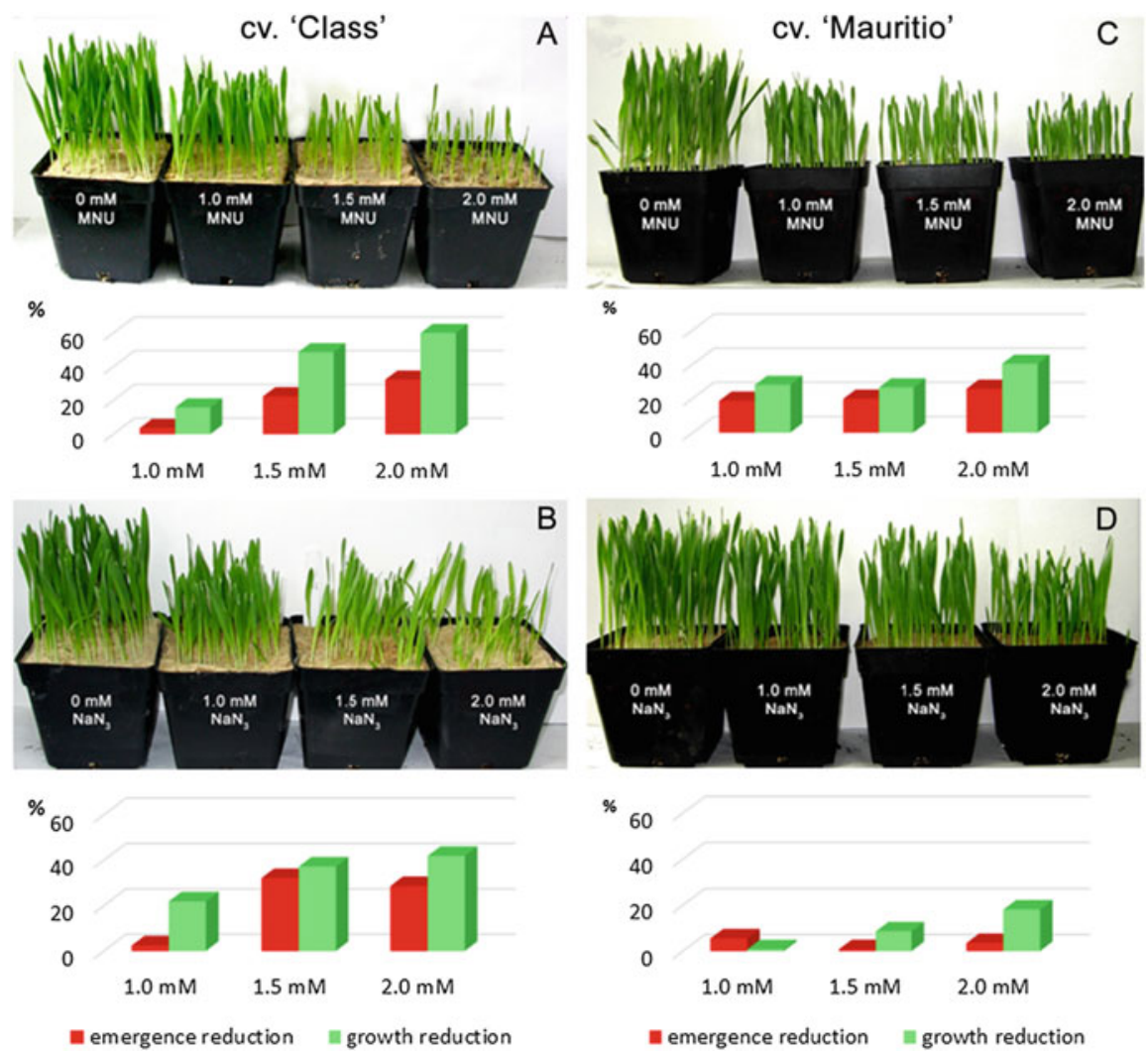

B
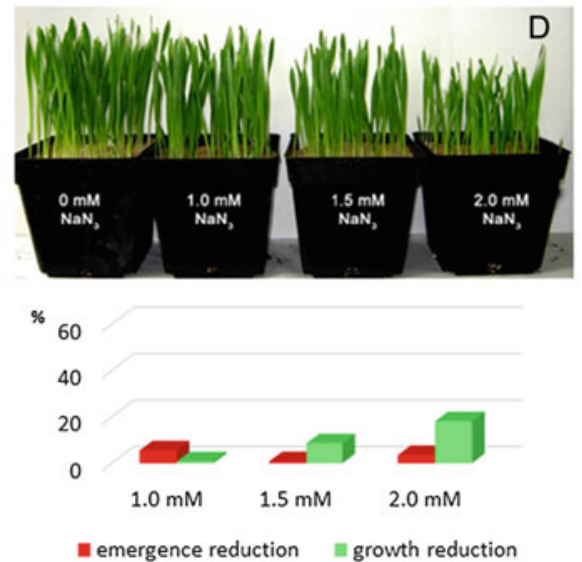

Fig. 6.1 Examples of different sensitivity of barley cultivars to mutagenic treatment. Laboratory tests for seedling emergence and growth reduction after mutagenic treatment of barley cv. 'Class' (A, B) and 'Mauritio' (C, D) with $\mathrm{MNU}(\mathbf{A}, \mathbf{C})$ and $\mathrm{NaN}_{3}(\mathbf{B}, \mathbf{D})$

\subsubsection{Handling of the Mutated Generations and the Basic Phenotyping of $M_{2}$ Plants and $M_{3}$ Lines}

1. Prepare a substrate-mix soil and vermiculite at a 2:1 ratio.

2. Plant the mutagenized seeds $\left(M_{1}\right)$ of spring cultivars into pots $(13-15-\mathrm{cm}$ diameter) and the seeds of winter genotypes into flats or small pots $(5 \mathrm{~cm}$ diameter) filled with the substrate. Two weeks after sowing, the seedlings of the winter genotypes are vernalized at $4{ }^{\circ} \mathrm{C}, 16 / 8 \mathrm{~h}$ photoperiod, light intensity $100 \mu \mathrm{mol} \mathrm{m} \mathrm{m}^{-2} \mathrm{~s}^{-1}$ for $8-10$ weeks, after which they are transferred to bigger pots and grown under the same conditions as the spring genotypes in a greenhouse or a growth room $\left(22 / 20{ }^{\circ} \mathrm{C}\right.$ day/night, $16 / 8$ photoperiod, light intensity $350-450 \mu \mathrm{mol} \mathrm{m} \mathrm{s}^{-1}$ ). (see Notes 14 and 15).

3. Assign a number to each $\mathbf{M}_{1}$ plant. Optimally, develop approximately 10,000 $\mathrm{M}_{1}$ plants. Remember to water and fertilize the plants regularly. 
4. Harvest $\mathbf{M}_{1}$ plants and establish a seed bank. Vacuum pack the dried $\mathbf{M}_{2}$ seeds from each $\mathrm{M}_{1}$ plant separately and store them in a freezer or cold chamber (at $4-5{ }^{\circ} \mathrm{C}$, optimally $-20{ }^{\circ} \mathrm{C}$ ).

5. Sow one seed from each $M_{1}$ plant into a $13-15-\mathrm{cm}$ pot. Only one $\mathrm{M}_{2}$ plant derived from each $\mathrm{M}_{1}$ individual is grown in order to avoid the repetition of the same mutations. Optionally, two seeds from the same plant can be sown in order to save time in the event that one of them does not germinate or is a chlorophyll mutant. If two $\mathrm{M}_{2}$ seedlings emerge, discard one of them. There should only be one $\mathrm{M}_{2}$ plant per pot.

6. Grow the $\mathrm{M}_{2}$ generation in a greenhouse or a growth room under optimal conditions (temperature $22 / 20{ }^{\circ} \mathrm{C}$ day/night, $16 / 8$ photoperiod, light intensity $\left.350-450 \mu \mathrm{mol} \mathrm{m}{ }^{-2} \mathrm{~s}^{-} 1\right)$. Remember to water the plants regularly. Fertilize them with 22:5:10 (N:P:K) fertilizer two to three times during vegetation. Assign the appropriate number to each $\mathrm{M}_{2}$ plant-for example, if the $\mathrm{M}_{2}$ seed was taken from $\mathrm{M}_{1}$ plant number 333 , name the $\mathrm{M}_{2}$ plant 333/01.

7. When the plants begin to tiller, collect leaf samples for DNA isolation. Isolate DNA from each $\mathrm{M}_{2}$ plant separately (see Sect. 6.3.3).

8. Observe the $\mathrm{M}_{2}$ plants for chlorophyll mutations at seedling stage (see Note 16) and any morphological changes during growth. Input the information about them into a database.

9. Before harvesting, perform a basic phenotype analysis of $\mathbf{M}_{2}$ plants. Collect the information on, e.g., plant height, culm length, spike length, spike morphology, awn length/shape, number of tillers, fertility/partial sterility, number and weight of $\mathrm{M}_{3}$ seeds, and any visible alterations. Input these data into a database.

10. Collect $\mathrm{M}_{3}$ seeds from each $\mathrm{M}_{2}$ plant separately.

11. Put the seeds of $\mathrm{M}_{3}$ and further generations into the seed bank. The seeds should be cleaned, dried, vacuum packed, and stored at a low moisture content (below $12 \%$-the moisture content can be monitored using a grain moisture meter) at a temperature below $10{ }^{\circ} \mathrm{C},\left(-20^{\circ} \mathrm{C}\right.$ is the best option, see Note 17$)$. Each package should be described with information on the plant ID, year of harvest, and optionally with the number and weight of the seeds. A label should be placed inside the package and printed out using non-bleaching ink (Fig. 6.2).

12. After the identification of a particular $\mathbf{M}_{2}$ plant carrying a mutation in the gene of interest (for methods of mutation identification, see Chaps. 17, 18, 19, and 20 of this book), use the seeds of its progeny for phenotyping (reverse approach). Only plants carrying the mutation in a homozygous state should be analyzed (see Note 18). It is important to multiply the homozygous material prior the detailed phenotypic analysis.

13. If a large number of $\mathrm{M}_{3}$ seeds from a particular $\mathrm{M}_{2}$ plant have been obtained, you can sow 15-20 $\mathrm{M}_{3}$ seeds in a field in order to check for any morphological traits and their segregation. $\mathrm{M}_{3}$ lines with positive traits may be used in breeding programs (forward approach). All data should be archived in the database.

14. Perform a backcross of an identified mutant with the parent variety in order to clean the genetic background of the mutant from other mutations. In the $\mathrm{BCF}_{2}$ 

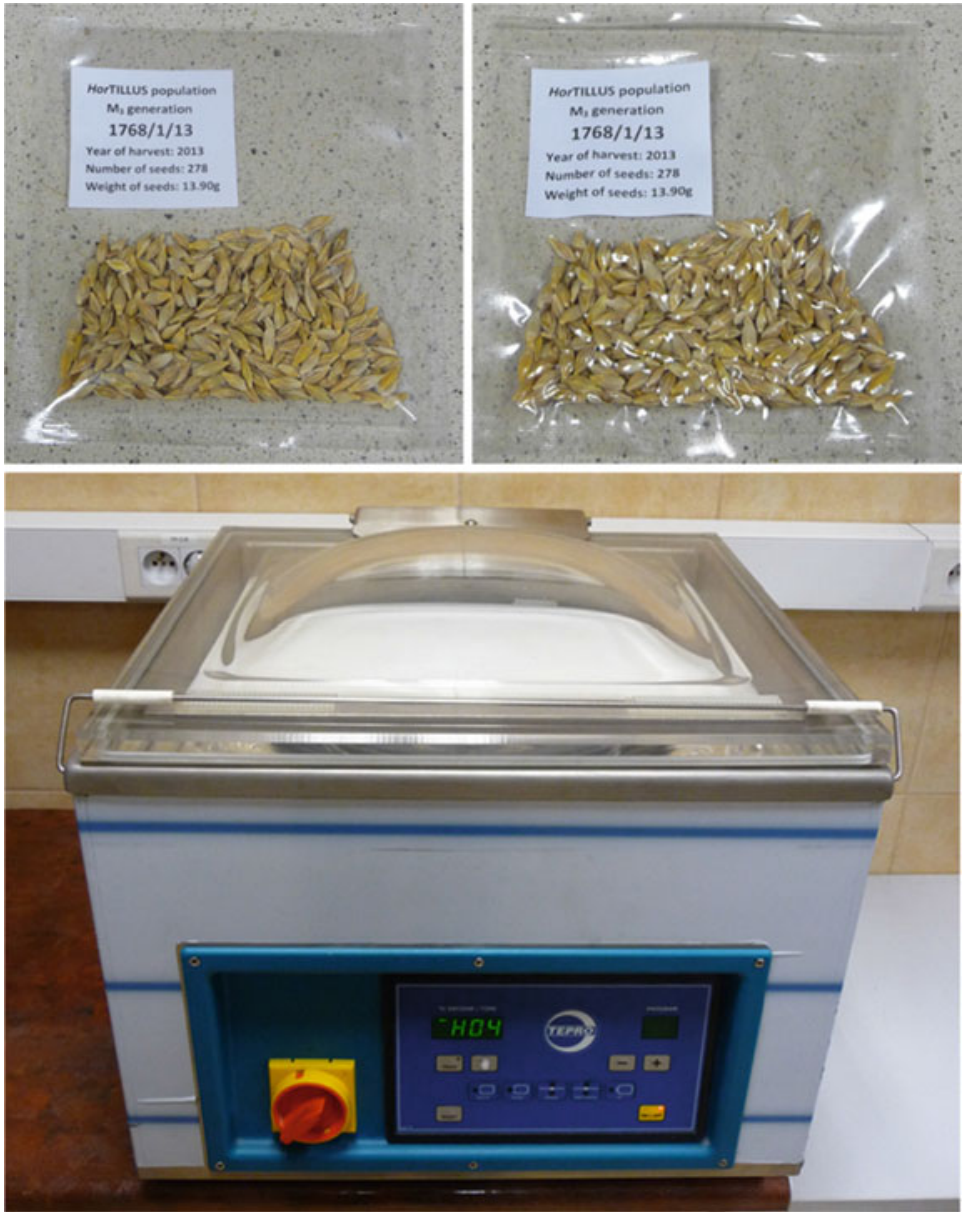

Fig. 6.2 Vacuum packer and seeds prepared for storage in a seed bank

generation, identify plants carrying a homozygous mutation in the analyzed gene. Use the $\mathrm{BCF}_{2}$ homozygous mutants for phenotyping, including a detailed evaluation of traits of interest. 


\subsubsection{DNA Isolation: Creating the $M_{2}$ DNA Library}

\subsubsection{Isolate DNA from the $\mathrm{M}_{2}$ Plants According to the Modified Micro-CTAB Method (Doyle and Doyle 1987 and see Note 19)}

The DNA of each $\mathrm{M}_{2}$ plant must be isolated and stored individually. Alternative DNA extraction methods can be considered (for example, see Chap. 14).

1. Dry leaves in silica gel for a minimum of 3 days.

2. Put dry fragments of leaves into 2.2-ml Eppendorf tubes together with three glass balls.

3. Grind the leaf tissue in an electric mill (45 min in a Retsch MM 200 or 301; $40 \mathrm{~s}$ in a FastPrep ${ }^{\circledR}-24$ homogenizer) in order to disrupt the tissue structure and cell walls.

4. Add $1 \mathrm{ml}$ of a CTAB extraction buffer heated to $60{ }^{\circ} \mathrm{C}$ to each tube in order to lyse the cell membranes.

5. Incubate samples in a water bath or thermomixer at $60{ }^{\circ} \mathrm{C}$ for $0.5 \mathrm{~h}$.

6. Add $800 \mu \mathrm{l}$ of chloroform-isoamyl alcohol (24:1) to each tube to denature the proteins and separate the aqueous and organic phases.

7. Centrifuge at $18,000 \times g$ at $4{ }^{\circ} \mathrm{C}$ for $20 \mathrm{~min}$.

8. Transfer the upper aqueous phase into a new tube; discard the lower organic phase.

9. Add $600 \mu \mathrm{l}$ of chloroform-isoamyl alcohol (24:1) to each tube.

10. Centrifuge at $18,000 \times g$ at $4{ }^{\circ} \mathrm{C}$ for $10 \mathrm{~min}$.

11. Transfer the upper aqueous phase into a new tube; discard the lower organic phase.

12. Add $1 \mathrm{ml}$ of $96 \%$ ethanol to each tube to precipitate DNA.

13. Centrifuge at $18,000 \times g$ at $4{ }^{\circ} \mathrm{C}$ for $30 \mathrm{~min}$.

14. Remove supernatant.

15. Add $1 \mathrm{ml}$ of $70 \%$ ethanol to each tube.

16. Centrifuge at $18,000 \times g$ at $4{ }^{\circ} \mathrm{C}$ for $5 \mathrm{~min}$.

17. Remove supernatant.

18. Repeat steps 15-17.

19. Dry the pellet, e.g., using a SpeedVac (Savant).

20. Add $100 \mu \mathrm{l}$ of a TE buffer to each tube to dissolve DNA.

21. Incubate samples at $37{ }^{\circ} \mathrm{C}$ for $20 \mathrm{~min}$ (or $4{ }^{\circ} \mathrm{C}$ overnight).

22. Add $1 \mu \mathrm{l}$ of an RNAse solution to each tube.

23. Incubate samples at $37{ }^{\circ} \mathrm{C}$ for $45 \mathrm{~min}$.

24. Measure the DNA concentration in each sample using a NanoDrop ND-1000.

25. Dilute DNA to a concentration of $100 \mathrm{ng} / \mu \mathrm{l}$.

26. Store the DNA (both, stocks and dilutions) at $-20{ }^{\circ} \mathrm{C}$. 


\subsubsection{Prepare Pools of DNA to Identify Plants Carrying Mutations Within the Gene of Interest}

Different pooling strategies are used for different mutation discovery methods (for example see Chaps. 18 and 20 of this book)

\subsubsection{Creation of a Database}

\subsubsection{General Information}

1. A database is composed of tables containing an unlimited number of columns that describe specific traits/information and an unlimited number of rows that represent individuals (plants, genes, mutations, etc.).

2. The structure of the tables can be modified at each stage of database creation.

3. The number of tables in a database is unlimited.

4. It is convenient to design individual tables for each generation or for each part of the presented studies.

5. Each table should contain a column with an ID number that allows information about a specific individual that is collected in different tables to be connected. This could be the name/number of a plant or an additional ID.

6. Each column in the tables should be defined in regard to data type (in numeric format, text format, data, etc.) and in regard to the symbol number that is used to describe this feature. This will allow space on the server to be saved and will ensure the efficient operation of the database.

7. Database users should never have direct access to the tables that contain the data. All operations, including adding, modifying, removing, and searching the data, should be done using forms that are prepared by the administrator. The forms, which are usually prepared in the HTML and PHP languages, can be created using special programs (web page editors, see Note 4) or using any text editor.

8. All operations during the creation of database and its administration can be done on files that are saved on the server, but it is more convenient to test all of the implemented solutions on a local computer and then to transfer them to the server. A freeware software such as a WampServer can be used to create a virtual server on a local computer (http://www.wampserver.com).

\subsubsection{Creation of a Database: An Example}

Information about a basic version of a database for a barley TILLING population is presented below. This database contains tables that describe the plants of the $M_{1}$, $\mathrm{M}_{2}$, and $\mathrm{M}_{3}$ generations, any identified mutations, and a large-scale screening analysis that were carried out in the developed population (see Note 19): 
1. Create Table "m1," which contains information about the plants of the $\mathrm{M}_{1}$ generation, such as the number of seeds collected from the main spike, the number of all of the seeds collected, the number of seeds that were planted for the development of $\mathrm{M}_{2}$, and the information about the mutagenesis when different treatments were used (Fig. 6.3a).

2. Create Table "m2," which contains columns that allow the data that describes the isolated DNA (quantity, quality, storage location), the basic phenotype of the $\mathrm{M}_{2}$ plants (see Sect. 6.3.2), other phenotypic changes, the number of $\mathrm{M}_{3}$ seeds produced by the $\mathrm{M}_{2}$ plants, and the current availability of $\mathrm{M}_{3}$ seeds (part of seeds might have been used up in experiments) to be stored (Fig. 6.3b).

3. Create the "mutations" table for the descriptions of the mutations identified in the $\mathrm{M}_{2}$ generation of the TILLING population. This table should contain information about the names/numbers of the $\mathrm{M}_{1}$ and $\mathrm{M}_{2}$ individuals, information about the genes that were analyzed (the name and sequence), information about the length of analyzed amplicon, and detailed information about mutationsposition in the analyzed sequence, mutation type, information about the homoor heterozygosity of mutation, allele name (Fig. 6.3c).

4. The TILLING population can be used for large-scale screening analysis in $\mathrm{M}_{3}$ or further generations. In this case, each individual plant should be identified by at least three columns: "m1_name," "m2_name," and "m3_name."

5. Regular backups of each table should be stored on a local computer.

6. After adding a large amount of data, the modified tables should be checked and optimized.

Notes

1. Selection of a cultivar or line for mutagenesis is a very important step. It depends on the goal of creation of a TILLING platform. The batch of seeds chosen for mutagenesis should be homozygous or near homozygous and should have a high germination capacity. Any seeds that are injured, are abnormal, or have symptoms of a disease should be discarded.

2. DNA isolation procedure should be performed under the fume hood, due to the usage of $\beta$-mercaptoethanol and chloroform. $\beta$-Mercaptoethanol should be added under the fume hood because of its extensive smell.

3. Most scientific institutions provide space on the institution's server for their employees. Otherwise, commercial services that provide the security and maintenance of the server can be used. It is also possible to develop a database on a server that is free of charge. However, this solution is not recommended due to the problems with data security and with unwanted advertisements being displayed while using a database. The space needed for the development of database on a server depends on the format of the data that will be stored. Pictures and all graphical files occupy much of the available space and 


\begin{tabular}{|c|c|c|c|c|c|c|}
\hline \multicolumn{7}{|c|}{ 'm1 table } \\
id & $\mathbf{m 1}$ name & harvest date & $\begin{array}{c}\text { harvest } \\
\text { single }\end{array}$ & $\begin{array}{c}\text { harvest } \\
\text { whole }\end{array}$ & $\begin{array}{c}\text { planted } \\
\text { single }\end{array}$ & $\begin{array}{c}\text { planted } \\
\text { whole }\end{array}$ \\
\hline$[\ldots]$ & {$[\ldots]$} & {$[\ldots]$} & {$[\ldots]$} & {$[\ldots]$} & {$[\ldots]$} & {$[\ldots]$} \\
8761 & 7009 & $2007-07-30$ & 4 & 2 & 1 & 0 \\
8762 & 7010 & $2007-07-30$ & 3 & 15 & 1 & 0 \\
{$[\ldots]$} & {$[\ldots]$} & {$[\ldots]$} & {$[\ldots]$} & {$[\ldots]$} & {$[\ldots]$} & {$[\ldots]$} \\
\hline
\end{tabular}

B

'm2' table

\begin{tabular}{|c|c|c|c|c|c|c|c|c|c|c|c|}
\hline id & $\begin{array}{c}\mathrm{m} 1 \\
\text { name }\end{array}$ & $\begin{array}{c}\mathrm{m} 2 \\
\text { name }\end{array}$ & $\begin{array}{l}\text { isolation } \\
\text { box }\end{array}$ & $\begin{array}{l}\text { isolation } \\
\text { quantity }\end{array}$ & $\begin{array}{c}\text { Isolation } \\
\text { quality }\end{array}$ & $\begin{array}{c}\text { post } \\
\text { height }\end{array}$ & $\begin{array}{l}\text { post } \\
\text { tillers }\end{array}$ & post fertility & $\begin{array}{c}\text { post seed } \\
\text { m3 }\end{array}$ & $\begin{array}{c}\begin{array}{c}\text { weight } \\
\text { seed } \mathrm{m} 3\end{array} \\
\end{array}$ & $\begin{array}{c}\text { post } \\
\text { others }\end{array}$ \\
\hline$[\ldots]$ & [...] & [...] & {$[\ldots]$} & {$[\ldots]$} & [...] & {$[\ldots]$} & {$[\ldots]$} & [...] & {$[\ldots]$} & {$[\ldots]$} & {$[\ldots]$} \\
\hline 14965 & 7009 & & 52-E-7 & 1895.2 & 1.99 & 71 & 9 & semifertile & 92 & 5.14 & none \\
\hline 14565 & . & & 52-E-8 & 3083.4 & 1.98 & 68 & 6 & semifertile & 105 & 4.78 & none \\
\hline$[\ldots]$ & {$[\ldots]$} & {$[$ [...] } & {$[\ldots]$} & {$[\ldots]$} & {$[\ldots]$} & [...] & {$[\ldots]$} & {$[\ldots]$} & {$[\ldots]$} & [...] & [...] \\
\hline
\end{tabular}

C
\begin{tabular}{|c|c|c|c|c|c|c|c|c|}
\hline id & gene name & acc no ncbi & nt seq & $\begin{array}{c}\text { amplicon } \\
\text { start }\end{array}$ & $\begin{array}{c}\text { amplicon } \\
\text { end }\end{array}$ & m1 name & m2 name & allele \\
\hline$[\ldots]$ & {$[\ldots]$} & {$[\ldots]$} & {$[\ldots]$} & {$[\ldots]$} & {$[\ldots]$} & {$[\ldots]$} & {$[\ldots]$} & {$[\ldots]$} \\
\hline 274 & HVSNAC1 & JF796130 & ATGGGG... & 1 & 1132 & 7009 & {$[\ldots]$} &.. \\
\hline 275 & HVSNAC1 & JF796130 & ATGGGG... & 1 & 1132 & 1825 & 1 & .0 \\
\hline$[\ldots]$ & {$[\ldots]$} & {$[\ldots]$} & {$[\ldots]$} & {$[\ldots]$} & {$[\ldots]$} & {$[\ldots]$} & {$[\ldots]$} & {$[\ldots]$} \\
\hline
\end{tabular}

\begin{tabular}{|c|c|c|c|c|c|c|c|c|c|}
\hline homo hetero & $\mathrm{nt}$ before & $\begin{array}{c}\mathrm{nt} \\
\text { position }\end{array}$ & $\mathrm{nt}$ after & localisation & $\begin{array}{c}\text { mutation } \\
\text { type }\end{array}$ & aa seq & $\begin{array}{c}\text { aa } \\
\text { before }\end{array}$ & $\begin{array}{c}\text { aa } \\
\text { position }\end{array}$ & $\begin{array}{c}\text { aa } \\
\text { after }\end{array}$ \\
\hline$[\ldots]$ & {$[\ldots]$} & {$[\ldots]$} & {$[\ldots]$} & {$[\ldots]$} & {$[\ldots]$} & {$[\ldots]$} & {$[\ldots]$} & {$[\ldots]$} & {$[\ldots]$} \\
\hline homo & $\mathrm{G}$ & 883 & $\mathrm{~A}$ & coding & silent & MGMPAA $\ldots$ & G & 295 & G \\
\hline homo & $\mathrm{G}$ & 965 & $\mathrm{~A}$ & coding & missense & MGMPAA... & G & 276 & $\mathrm{~S}$ \\
\hline$[\ldots]$ & {$[\ldots]$} & {$[\ldots]$} & {$[\ldots]$} & {$[\ldots]$} & {$[\ldots]$} & {$[\ldots]$} & {$[\ldots]$} & {$[\ldots]$} & {$[\ldots]$} \\
\hline
\end{tabular}

Fig. 6.3 Examples of database tables with information about the $\mathrm{M}_{1}(\mathbf{A})$ and $\mathrm{M}_{2}(\mathbf{B})$ generations and the mutations identified in the analyzed genes $(\mathbf{C})$. The scheme shows three independent tables; red and green circles indicate how information from different tables can be related using the names of the $\mathrm{M}_{1}$ plants. Columns: "m1_name," "m2_name" contain information about the specific names of the analyzed plants; "harvest single" and "harvest whole," number of seeds from the apical spike and other spikes; "planted single" and "planted whole," number of seeds already used; "isolation box," storage location of the isolated DNA; "isolation quality" and "isolation quantity," describe the quantity (ng/ $\mathrm{ll}$ ) and quality (260/280 absorbance) of isolated DNA; "post height," height of mature plants; "post tillers," number of tillers; "post seed m3" and "seed weight m3," number and weight of the collected $\mathrm{M}_{3}$ seeds; "gene name," name of an analyzed gene; "acc no ncbi," NCBI accession number of the gene; "nt seq," nucleotide sequence of gene; "amplicon start" and "amplicon end," position of the analyzed amplicon in the sequence from the previous column; "allele," name of the identified allele; "homo hetero," mutation zygosity; "nt before," nucleotide in the original sequence; "nt position," position of the identified mutation; "nt after," mutated nucleotide; "localization," information about mutation position in the coding or noncoding sequence; "mutation type," type of the identified mutation; "aa seq," amino acid sequence; "aa before," amino acid in the original sequence; "aa position," position of the aa substitution in the protein; "aa after," the changed amino acid

significantly increase the transfer rate needed to use the database. For a simple database that contains data in a text file, at least $0.5 \mathrm{~GB}$ of space is recommended.

4. For the creation of a database and the individual tables, we recommend the freeware phpMyAdmin, which is installed by default on most servers. phpMyAdmin may also be downloaded from http://www.phpmyadmin.net. 
However, any other program for database creation and management can be used, such as Aptana Studio (http://www.aptana.com), Komodo Edit (http:// www.komodoide.com) or Eclipse (https://www.eclipse.org).

5. It should be stressed that most chemical mutagens are also strong carcinogens. For this reason, all steps of mutagenic treatment should be carried out under a biohazard fume hood. Disposable gloves and a lab coat should be used when performing treatments and dealing with treated seeds. Taking these precautions is especially important during treatment with MNU—a strong mutagen and carcinogen.

6. There are four main steps in mutagenic treatment of seeds with chemical mutagens:

- Presoaking the seeds in distilled water (see also Note 10)

- Treatment with the mutagen

- Posttreatment rinsing in tap water

- Planting the $\mathrm{M}_{1}$ seeds

7. When a double treatment with two mutagens is performed, the regular protocol of mutagenic treatment is followed with the addition of the 5-6-h interincubation germination period between treatments during which the seeds are incubated on a wet filter paper.

8. The concentration of the mutagen should be considered together with duration of the treatment. A shorter treatment time with a higher concentration of mutagen can increase somatic effects and could be insufficient to penetrate equally all cells in the plant material.

9. In addition to DNA lesions in the nucleus and cytoplasmic organelles, mutagens can generate damages in all components of cytosol and disturbances of the cell cycle. Therefore, mutagenic treatment can impair metabolism of cells in various tissues and organs and influence the growth and development of $\mathrm{M}_{1}$ plants. These effects, called "somatic effects" of mutagen, are manifested by delay in seed germination, reduction of plant emergence, growth reduction, appearance of chlorophyll defects, reduction of fertility, and plant survival. The size of the $\mathrm{M}_{1}$ generation should be calculated taking into account the lethality and sterility of $\mathrm{M}_{1}$ plants in order to guarantee enough seeds for $\mathrm{M}_{2}$ generation. It is worthwhile to organize a pilot experiment to help compare the somatic and genetic effects induced by a range of doses. The pilot experiment will extend the whole procedure but it helps in a proper selection of the dosages for the large-scale treatment.

10. The presoaking in distilled water should be applied to activate seeds physiologically before treatment with mutagen. Eight hours of presoaking at room temperature $\left(20-24{ }^{\circ} \mathrm{C}\right)$ is the optimal time for barley, but for convenience the seeds can be presoaked overnight. The presoaking reduces the somatic effect of chemical mutagen.

11. Sodium azide is a very efficient mutagen in several species if applied at low $\mathrm{pH}(<4)$. For barley mutagenesis, sodium azide is dissolved in a phosphate buffer at $\mathrm{pH}=3$, and this solution is used for treatment. 
12. The extensive posttreatment rinsing in tap water is necessary to stop the action of the mutagen and to remove its residues from the surface of the seeds. To facilitate sowing, the treated seeds can be dried on a filter paper under a fume hood. However, too intensive drying, especially at increased air temperature, can enhance somatic effects of the mutagen.

13. If a net is placed over the incubation beaker, that would protect seed from falling out.

14. If the appropriate space in the greenhouse or the growth room for growing $M_{1}$ generation is not available, the $\mathrm{M}_{1}$ plants can be grown in an experimental field, but the size of the population should be increased.

15. Optionally, $\mathrm{M}_{1}$ seeds of spring cultivars may be planted into small pots filled with the same substrate and kept for two weeks in a cold growth chamber $\left(4{ }^{\circ} \mathrm{C}\right.$, $16 / 8$ photoperiod, light intensity $100 \mu \mathrm{mol} \mathrm{m} \mathrm{m}^{-2} \mathrm{~s}^{-1}$ ) for hardening. After this period, the seedlings may be transplanted into bigger pots $(13-15 \mathrm{~cm})$ and grow them under the greenhouse conditions until harvesting.

16. The analysis of chlorophyll mutations is based on visual observation. There are several types of chlorophyll mutations that can be observed at seedling stage in barley. The most common are: albina (white), xantha (yellow), and viridis (pale green). The other categories include alboviridis (partially white and pale green), tigrina (with transverse yellow or necrotic stripes), and striata (with longitudinal, narrow white stripes).

17. The seed bank for seed storage is a crucial element of a TILLING platform. Proper maintenance of seeds will allow a TILLING platform to be a longlasting, renewable source of mutations for studies. Nevertheless, after several years of storing, the germination capacity of $\mathrm{M}_{3}$ seeds should be checked out, and when it is low, the remaining seeds should be multiplied. $\mathrm{M}_{3}$ plants should be harvested individually and the track of $\mathrm{M}_{3}$ and $\mathrm{M}_{4}$ origin from each individual $\mathrm{M}_{2}$ plant should be kept. Optionally, the whole $\mathrm{M}_{3}$ progeny derived from the same $\mathrm{M}_{2}$ plant can be bulked, but in this case, the identification of plants carrying mutation in the homozygous state might be more difficult.

18. Most of mutations are recessive; therefore, it is crucial to develop homozygous lines of mutants before phenotyping.

19. The database that is established on a server can be used as a local variant without publication on the Internet or as a public version. In both cases, the forms (HTML + PHP) should be used to manage the database. Never allow users to work on database with access to the administrator rights.

Acknowledgments This work was supported by the European Regional Development Fund through the Innovative Economy for Poland 2007-2013, project WND-POIG.01.03.01-00-101/ 08 POLAPGEN-BD task 22, by the Food and Agriculture Organization of the United Nations and the International Atomic Energy Agency through their Joint FAO/IAEA Programme of Nuclear Techniques in Food and Agriculture through Research Contract No.15419 of IAEA Coordinated Research Project D24012 and the Polish Ministry of Science and Higher Education (Grant No. 2080/IAEA/2011/0, 2557/FAO/IAEA/2012/0, 2904/FAO/IAEA/2013/0). 
Open Access This chapter is distributed under the terms of the Creative Commons AttributionNoncommercial 2.5 License (http://creativecommons.org/licenses/by-nc/2.5/) which permits any noncommercial use, distribution, and reproduction in any medium, provided the original author (s) and source are credited.

The images or other third party material in this chapter are included in the work's Creative Commons license, unless indicated otherwise in the credit line; if such material is not included in the work's Creative Commons license and the respective action is not permitted by statutory regulation, users will need to obtain permission from the license holder to duplicate, adapt or reproduce the material.

\section{References}

Caldwell D, McCallum N, Shaw P, Muehlbauer G, Marshall D, Waugh R (2004) A structured mutant population for forward and reverse genetics in barley (Hordeum vulgare L.). Plant $\mathbf{J}$ 40:143-150

Chawade A, Sikora P, Bräutigam M, Larsson M, Vivekanand V, Nakash MA, Chen T, Olsson O (2010) Development and characterization of an oat TILLING-population and identification of mutations in lignin and $\beta$-glucan biosynthesis genes. BMC Plant Biol 10:1-13

Cooper JL, Till BJ, Laport RG, Darlow MC, Kleffner JM, Jamai A, El-Mellouki T, Liu S, Ritchie R, Nielsen N, Bilyeu KD, Meksem K, Comai L, Henikoff S (2008) TILLING to detect induced mutations in soybean. BMC Plant Biol 8:1-10

Coronel C, Morris S (2016) Database systems: design, implementation and management. Cengage Learning, Boston, USA

Dahmani-Mardas F, Troadec C, Boualem A, Lévêque S, Alsadon AA, Aldoss AA, Dogimont C, Bendahmane A (2010) Engineering melon plants with improved fruit shelf life using the TILLING approach. PLoS One 5:1-9

Doyle JJ, Doyle JL (1987) A rapid DNA isolation procedure for small quantities of fresh leaf tissue. Phytochem Bull 19:11-15

Gottwald S, Bauer P, Komatsuda T, Lundqvist U, Stein N (2009) TILLING in the two-rowed barley cultivar 'Barke' reveals preferred sites of functional diversity in the gene HvHox1. BMC Res Notes 2:1-14

Gruszka D, Szarejko I, Maluszynski M (2012) Sodium azide as a mutagen. In: Shu QY, Forster BP, Nakagawa H (eds) Plant mutation breeding and biotechnology. CABI, The United Kingdom, pp. $159-166$

International Barley Genome Sequencing Consortium, Mayer KF, Waugh R, Brown JW, Schulman A, Langridge P, Platzer M, Fincher GB, Muehlbauer GJ, Sato K, Close TJ, Wise RP, Stein N (2012) A physical, genetic and functional sequence assembly of the barley genome. Nature 491:711-716

Kleibl K (2002) Molecular mechanisms of adaptive response to alkylating agents in Escherichia coli and some remarks on $\mathrm{O}^{6}$-methylguanine DNA methyltransferase in other organisms. Mutat Res 512:67-84

Kleinhofs A, Owais WM, Nilan RA (1978) Azide. Mutat Res 55:165-195

Kurowska M, Daszkowska-Golec A, Gruszka D, Marzec M, Szurman M, Szarejko I, Maluszynski M (2011) TILLING—a shortcut in functional genomics. J Appl Genet 52:371-390

Kurowska M, Labocha-Pawłowska A, Gnizda D, Maluszynski M, Szarejko I (2012) Molecular analysis of point mutations in a barley genome exposed to MNU and gamma rays. Mutat Res 738-739:52-70

Lababidi S, Mejlhede N, Rasmussen S, Backes G, Al-Said W, Baum M, Jahoor A (2009) Identification of barley mutants in the cultivar 'Lux' at the Dhn loci through TILLING. Plant Breed 128:332-336 
Maluszynski M, Szarejko I, Maluszynska J (2003) Mutation techniques. In: Thomas B, Murphy DJ, Murray BG (eds) Encyclopedia of applied plant sciences. Elsevier Academic, The United States of America, pp. 186-201

Maluszynski M, Szarejko I, Bhatia R, Nichterlein K, Lagoda PJL (2009) Mutation techniques. In: Guimares E, Ceccarelli S, Weltzein E, Rajendran PG (eds) Plant breeding book. FAO, Rome, pp. 159-194

Martín B, Ramiro M, Martínez-Zapater JM, Alonso-Blanco C (2009) A high-density collection of EMS-induced mutations for TILLING in Landsberg erecta genetic background of Arabidopsis. BMC Plant Biol 9(147):1-9

Marzec M, Gruszka D, Tylec P, Szarejko I (2016) Identification and functional analysis of the HvD14 gene that is involved in strigolactone signalling in Hordeum vulgare L. Physiol Plantarum. doi:10.1111/ppl.12460

McCallum C, Comai L, Greene E, Henikoff S (2000) Targeted screening for induced mutations. Nat Biotechnol 18:455-457

Mendiondo GM, Gibbs DJ, Szurman-Zubrzycka M, Korn A, Marquez J, Szarejko I, Maluszynski M, King J, Axcell B, Smart K, Corbineau F, Holdsworth MJ (2016) Enhanced waterlogging tolerance in barley by manipulation of expression of the $\mathrm{N}$-end rule pathway E3 ligase PROTEOLYSIS6. Plant Biotechnol J 14:40-50

Miller L (2014) An integrative business case utilizing an online database. J Bus Case Stud 10:21

Nilan RA, Sideris EG, Kleinhofs A, Sander C, Konzak CF (1973) Azide—a potent mutagen. Mutat Res 17:142-144

Okabe Y, Asamizu E, Saito T, Matsukura C, Ariizumi T, Mizoguchi T, Ezura H (2011) Tomato TILLING technology: development of a reverse genetics tool for the efficient isolation of mutants from Micro-Tom mutant libraries. Plant Cell Physiol 52:1994-2005

Olsen O, Wang X, von Wettstein D (1993) Sodium azide mutagenesis: preferential generation of A-T G-C transitions in the barley Ant18 gene. PNAS 90:8043-8047

Richardson KK, Richardson FC, Croby RM, Swenberg JA, Skopek TR (1986) DNA base changes and alkylation following in vivo exposure of Escherichia coli to N-methyl-N-nitrosourea or N-ethyl-N-nitrosourea. PNAS 84:344-348

Salvi S, Druka A, Milner SG, Gruszka D (2014) Induced genetic variation, TILLING and NGS-based cloning. In: Kumlehn J, Stein N (eds) Biotechnological Approaches to Barley Improvement, Biotechnology in Agriculture and Forestry 69. Springer, Berlin, Heidelberg. doi:10.1007/978-3-662-44406-1_15

Sato Y, Shirasawa K, Takahashi Y, Nishimura M, Nishio T (2006) Mutant selection from progeny of gamma-ray-irradiated rice by DNA heteroduplex cleavage using Brassica petiole extract. Breed Sci 56:179-183

Slade AJ, Knauf VC (2005) TILLING moves beyond functional genomics into crop improvement. Transgenic Res 14:109-115

Sparla F, Falini G, Botticella E, Pirone C, Talamè V, Bovina R, Salvi S, Tuberosa R, Sestili F, Trost P (2014) New starch phenotypes produced by TILLING in barley. PLoS One. doi:10. 1371/journal.pone.0107779

Stolarek M, Gruszka D, Braszewska-Zalewska A, Maluszynski M (2015a) Functional analysis of the new barley gene $H v K u 80$ indicates that it plays a key role in double-strand DNA break repair and telomere length regulation. Mutagenesis 30:785-797

Stolarek M, Gruszka D, Braszewska-Zalewska A, Maluszynski M (2015b) Alleles of newly identified barley gene $H v P A R P 3$ exhibit changes in efficiency of DNA repair. DNA Repair 28:116-130

Suzuki T, Eiguchi M, Kumamaru T, Satoh H, Matsusaka H, Moriguchi K, Nagato Y, Kurata N (2008) MNU-induced mutant pools and high performance TILLING enable finding of any gene mutation in rice. Mol Genet Genomics 279:213-223

Szarejko I, Maluszynski M (1980) Translocations and inversions in barley induced by fast neutrons and N-nitroso-N-methylurea (MNUA). Barley Genet Newslett 10:67-69 
Szarejko I, Maluszynski M (1999) High frequency of mutations after mutagenic treatment of barley seeds with $\mathrm{NaN3}$ and $\mathrm{MNH}$ with application of inter-incubation germination period. Mutat Breed Newslett 44:28-30

Talamè V, Bovina R, Sanguineti M, Tuberosa R, Lundqvist U, Salvi S (2008) TILLMore, a resource for the discovery of chemically induced mutations in barley. Plant Biotechnol $\mathrm{J}$ 6:477-485

Till BJ, Reynolds SH, Greene EA, Codomo CA, Enns LC, Johnson JE, Burtner C, Odden AR, Young K, Taylor NE, Henikoff JG, Comai L, Henikoff S (2003) Large-scale discovery of induced point mutations with high-throughput TILLING. Genome Res 13:524-530

Till BJ, Cooper J, Tai TH, Colowit P, Greene EA, Henikoff S, Comai L (2007) Discovery of chemically induced mutations in rice by TILLING. BMC Plant Biol 7:19

Warren JJ, Forsberg LJ, Bees LS (2006) The structural basis for the mutagenicity of $\mathrm{O}^{6}$-methylguanine lesion. PNAS 103:19701-19706

Xin Z, Wang ML, Barkley NA, Burow G, Franks C, Pederson G, Burke J (2008) Applying genotyping (TILLING) and phenotyping analyses to elucidate gene function in a chemically induced sorghum mutant population. BMC Plant Biol 8:1-14 